\title{
Adverse Genetic Correlations and Impacts of Silviculture Involving Wood Properties: Analysis of Issues for Radiata Pine
}

\author{
Rowland D. Burdon * (i) and John R. Moore \\ Scion (New Zealand Forest Research Institute Ltd.), Private Bag 3020, Rotorua 3046, New Zealand; \\ john.moore@scionresearch.com \\ * Correspondence: rowland.burdon@scionresearch.com; Tel.: +64-7-343-5742
}

Received: 13 April 2018; Accepted: 26 May 2018; Published: 1 June 2018

\begin{abstract}
Plantation forestry is now an imperative to meet wood requirements efficiently on the finite land available for wood production. Three main determinants of profitability are productivity, price per unit of wood harvested, and harvest age (the sooner the better). The first two are largely self-evident, while reducing harvest age lowers the effective cost of growing wood. Among these determinants, however, are strong interplays which include trade-offs. Key trade-offs involve adverse genetic correlations between various wood properties and growth-rate variables, and adverse effects on the wood quality of silvicultural interventions that raise site productivity and/or reduce harvest age. Moreover, the adverse effects of silviculture on wood properties tend to be accompanied by heightened expressions of genetic variation in wood properties. The trade-offs involve both increasing the percentage of corewood ('juvenile wood') and some more direct effects on wood quality. The pervasiveness of the trade-offs, and the heightened genetic expression, accentuate the call for genetic selection to defend wood quality. Such selection, however, will entail some costs in the appropriate emphasis on breeding for productivity. In this paper we review these issues, identify gaps in research information and offer guidance for tree breeders and silviculturists. While radiata pine is the special case, the applicability to some other species is briefly discussed.
\end{abstract}

Keywords: corewood; genetic parameters; Pinus radiata; plantations; productivity; profitability; silviculture; tree breeding; wood properties; wood quality

\section{Introduction}

The need for plantation forestry, to meet global needs for wood supplies and various environmental services is well documented [1,2]. Profitability must nonetheless be addressed. Three main determinants of it are productivity in terms of the amount of wood grown per unit time, price per unit volume of that wood, and harvest age through earlier harvests reducing the effective growing costs [3]. While profitability of forest plantations can be assessed through measures such as "stumpage" (harvest revenues less harvesting and transport costs), two other measures are widely seen as more rigorous. These are Net Present Value (NPV) (for a given discount rate) and Internal Rate of Return (IRR). These latter measures account for the time cost of money and the time taken between incurring costs and realising revenues. Therefore, harvest age can have large influences on NPV, particularly at high discount rates, and on IRR. Intensive forest management has been used as a means of raising forest productivity (Productivity is widely equated with the volume of stemwood produced per ha per annum. This criterion, which we generally adopt here, may suffice for producing appearance-grade solid-wood products. However, it will often give an inflated measure of relative differences in stem biomass production, which will be more relevant, 
say, for pulp production.) and reducing rotation length $[4,5]$. The main interventions that can raise productivity fall into two broad categories, namely genetic improvement and silvicultural measures [6-8]. Genetic improvement involves selective breeding, delivery systems for genetic gain, and customised deployment of improved breeds or clones to sites and silvicultural regimes. Also, genetic improvement is directed at all determinants of profitability, the appropriate emphasis on individual determinants depending on the particular context. Regarding silvicultural interventions, good plantation establishment is viewed as a basic precondition. Beyond that, possible interventions include measures to (1) raise or defend site productivity, notably by fertiliser use and control of competing vegetation, pests and diseases; (2) ensure through stocking control both the full use of site resources and concentration of growth in target trees; and (3) enhance or defend wood quality largely by manipulation of stocking. These interventions are subject to interplays and trade-offs. Accumulated or inferred information on these effects is summarised in Table 1, under the two main categories of intervention. For each category, the scope for improvements is reviewed, and then the trade-offs and other constraints are considered. The effects are considered in detail in later text.

Table 1. Interplays between determinants of profitability and genetics and silviculture, in radiata pine, with main qualitative relationships indicated above diagonal, and main mechanisms for effects below diagonal, and directly beneficial measures on diagonal.

\begin{tabular}{|c|c|c|c|c|c|}
\hline \multirow[b]{2}{*}{ Factor } & \multicolumn{3}{|c|}{ Determinant of Profitability } & \multicolumn{2}{|c|}{ Intervention } \\
\hline & Productivity & $\begin{array}{l}\text { Wood Quality } \\
\text { (WQ) }\end{array}$ & Harvest Age & Genetics & Silviculture \\
\hline Productivity & $\begin{array}{l}\text { Selective breeding, site } \\
\text { amelioration, } \\
\text { weed/pest control }\end{array}$ & -- & \pm \pm & ++ & \pm \pm \\
\hline $\begin{array}{l}\text { Wood quality } \\
\text { (assumed to be } \\
\text { reflected in } \\
\text { prices) }\end{array}$ & $\begin{array}{l}\text { Adverse genetic } \\
\text { correlations with WQ } \\
\text { Impacts of silviculture }\end{array}$ & $\begin{array}{l}\text { Selective breeding, } \\
\text { longer rotations }\end{array}$ & -- & ++ & \pm \pm \\
\hline $\begin{array}{l}\text { Harvest age } \\
\text { (earlier } \\
\text { preferred) }\end{array}$ & $\begin{array}{l}+: \text { Effect of lower } \\
\text { stockings, genotype for } \\
\text { growth rate } \\
\text {-: Lower stocking }\end{array}$ & $\begin{array}{l}-: \text { Increased } \\
\text { corewood content } \\
(-) \text { : More direct } \\
\text { adverse effects }\end{array}$ & $\begin{array}{l}\text { lower } \\
\text { stockings, site } \\
\text { amelioration }\end{array}$ & + & ++ \\
\hline Genetics & $\begin{array}{l}\text { Heritability and } \\
\text { variability }\end{array}$ & $\begin{array}{l}\text { Adverse genetic } \\
\text { correlations with } \\
\text { growth-rate } \\
\text { variables }\end{array}$ & $\begin{array}{l}\text { Genetic gain in } \\
\text { growth rate }\end{array}$ & $\begin{array}{l}\text { Selective } \\
\text { breeding and } \\
\text { deployment }\end{array}$ & + \\
\hline Silviculture & $\begin{array}{l}+: \text { Higher stocking } \\
-: \text { Lower stocking to } \\
\text { reduce harvest age }\end{array}$ & $\begin{array}{l}++ \text { Longer } \\
\text { rotations } \\
--: \text { Accelerated } \\
\text { diameter growth }\end{array}$ & $\begin{array}{l}++ \text { Site } \\
\text { amelioration, } \\
\text { lower stocking, } \\
\text { genetic gains in } \\
\text { growth rate }\end{array}$ & $\begin{array}{l}\text { + Flexibility in } \\
\text { stocking, } \\
\text { customising } \\
\text { silviculture to } \\
\text { improved } \\
\text { breeds }\end{array}$ & $\begin{array}{l}\text { Site } \\
\text { amelioration, } \\
\text { manipulating } \\
\text { stocking, } \\
\text { Setting final } \\
\text { harvest age }\end{array}$ \\
\hline
\end{tabular}

Plus signs (+) denote favourable effects, minus signs ( - ) adverse effects, and \pm denotes mixed effects. Numbers of sign symbols denote putative general magnitude of effects be they favourable or adverse.

Effects on wood properties of interventions that boost productivity and/or reduce harvest age involve both increases in the percentage of corewood (A traditional term for corewood is juvenile wood', but the corewood-outerwood progression is a different phenomenon from what maturation in woody plants is now understood to be [9].) and some more direct effects. For most purposes they tend to be adverse, often strongly so. Specific features of corewood and its radial progression into outerwood $[9,10]$ are summarised for radiata pine (Pinus radiata D. Don) in Table 2. For most wood properties the initial radial progression is steep, followed by asymptotic approaches to outerwood values [11,12]. One exception is spiral grain angle, which typically shows an initial increase before dropping more or less asymptotically [13]. The detailed pith-to-bark trajectories in relation to ring numbers from the pith differ markedly among properties, and for individual properties they can differ appreciably among trees. 
Table 2. Behaviour of some individual wood properties in the corewood-outerwood progression in radiata pine, with inferred drivers or components.

\begin{tabular}{|c|c|}
\hline Property & Main Driver(s) or Components of Progression (Known or Putative) \\
\hline \multicolumn{2}{|l|}{ Increasing } \\
\hline Basic density & Endogenous? Latewood \%, Wall thickness \\
\hline Latewood percent & Endogenous? Inter-tree competition, Distance from crown \\
\hline Stiffness (Modulus of elasticity) * & Density, MfA, Reduced spirality? \\
\hline Strength (Modulus of rupture) & Density, Tracheid length \\
\hline Side hardness & Density \\
\hline Tracheid length & Endogenous? \\
\hline Tracheid wall thickness & Endogenous, Distance from crown \\
\hline Dimensional stability * & MfA, Grain spirality \\
\hline \multicolumn{2}{|l|}{ Decreasing } \\
\hline Ring width & Geometry, Inter-tree competition, Eventual decline in vigour \\
\hline Microfibril angle (MfA) & Endogenous? \\
\hline Grain spirality & Obliteration of fascicle phyllotaxy? Other endogenous? \\
\hline Tracheid radial width & Endogenous? Distance from crown, Inter-tree competition \\
\hline Drying degrade * & Density, MfA? \\
\hline
\end{tabular}

Categories of growing and harvesting costs, other than those governed by harvest age, are also important for profitability, but are not generally addressed except insofar as they are affected by genetic improvement or are flow-on effects of silvicultural intervention.

While wood quality is often defined in terms of basic wood properties [14], we deem it to include here the occurrence and nature of defects. In radiata pine the defects are typically dominated by knots, the sizes of which reflect branch diameters which in turn are greatly influenced by both silviculture and genetics. Other defects include knots, grain distortion, zones of reaction wood, resin features ("resin pockets" or "external resin bleeding") and intra-ring checks ("internal checking") [15,16]. Grain distortion and the presence of reaction wood tend to reflect malformation incidence which can also be greatly influenced by silviculture as well as some genetic influences. Importantly, as is discussed later, the silvicultural influences tend to be closely parallel for basic wood properties and the severity and incidence of defects.

This paper is a review that is essentially an analysis of the issues, with the objective of providing pointers for further research and for practicing tree breeders and silviculturists. It is based above all on long and intimate experience with a species that has been the subject of much cutting-edge work in developing modern plantation forestry $[7,8]$. We consider the issues under the two main categories of intervention, first genetic improvement, and then silvicultural inputs, both as primarily means of improving productivity. For each category we consider the position with respect to the following: The scope, proven and potential, for improving productivity and/or advancing harvest age; more specific avenues for achieving these objectives; and how trade-offs involving these objectives and wood quality arise and may be countered or at least managed. During the course of this, we identify areas where putative information needs to be tested and supplemented by additional concrete data [17], along with other knowledge gaps. Before the concluding section, we briefly review the context of coming advances in gene technology, and then how the wood-quality issues are likely to apply to a few other tree species. In concluding, we emphasise how the inherently adverse effects of both genetic improvement and silvicultural interventions to boost productivity and/or reduce harvest age converge on a need for genetic selection to defend wood quality. It is important to note that we are not offering an exhaustive literature review. 


\section{Genetic Improvement}

\subsection{Scope and Attainments to Date}

The scope for genetic improvement in any one trait is governed by the heritability multiplied by the coefficient of variation (CV). In radiata pine plenty of scope exists for genetic improvement in productivity and wood properties, although there are constraints on the genetic gain achievable on both fronts. For growth traits the scope is dominated by high variability, with correspondingly high CVs, which compensate for typically low to moderate heritability. The expectations have been borne out by demonstrated gains in productivity from genetic selection [18]. Also, dramatic genetic improvement was achieved, even from initial plus-tree selection, in tree form and general log quality; this had the flow-on benefit of averting the requirement for high initial planting densities, with reduced planting and tending costs [7]. Such gains, along with genetic gains in growth rate, have led to widespread uptake on the part of industry; nurserymen and forest growers have been paying price premiums for genetically improved seed and nursery stock, the premiums depending on the level of genetic improvement. Continuing genetic gains can be expected. However, their magnitude in per-hectare yields is currently uncertain, because faster individual-tree growth rates will accelerate between-tree competition and the approach to crop 'carrying capacity.' Inherent productivity will need to be defended on at least some sites, often by breeding for disease resistance, e.g., [19-22]; however, genetic gains in resistance or tolerance will tend to be achieved at the expense of some potential genetic gains in productivity for disease-free situations.

Wood properties generally show moderate to high heritability (see review by Wu et al. [23,24]), with rankings of individual genotypes varying little among environments, i.e., with little rank-change genotype-environment interaction [25-27]. In particular, wood density is highly heritable, across sites as well as within sites. Wood density governs several wood properties of more immediate economic importance, so while its CV among neighbouring trees is only modest (typically ca $8 \%$, depending on the wood-density variable), this can translate into much larger CVs for wood-performance traits like modulus of elasticity (stiffness) and modulus of rupture (strength) [28]. However, despite the scope for genetic improvement of wood properties, emphasis on their genetic improvement came relatively late compared with improvements in growth traits [29]. This resulted from a combination of factors [8,30], notably unwillingness of industry parties to accept sacrifice of potential gains in wood volume production when there are few if any current price signals in the market to warrant this, and the difficulties and costs of assay for some important wood properties. However, with a reduction in rotation age and aggressive thinning regimes, a general decline in wood properties became a major concern $[29,31]$, while assays for wood properties have become much cheaper and more powerful $[32,33]$, so in recent years tree breeders have sharply increased the emphasis on the genetic improvement of wood properties [8,34].

\subsection{Genetic Parameters and Their Implications}

Meeting the call for genetic improvement in both productivity and wood properties faces the classic issues of multi-trait selection. In principle, an optimal solution lies in a selection index (I), which is a linear function of phenotypic values for several traits that represent or are predictive of the breeding goal, i.e.,

$$
\mathrm{I}=\mathrm{b}_{1} \mathrm{P}_{1}+\mathrm{b}_{2} \mathrm{P}_{2}+\ldots+\mathrm{b}_{\mathrm{n}} \mathrm{P}_{\mathrm{n}}
$$

where $P_{1}, \ldots, P_{n}$ are the observed phenotypic values for the traits of interest and $b_{1}, \ldots, b_{n}$ are weights assigned to these traits in the selection index. The classic selection index is the Smith-Hazel index [6] (pp. 349-352), [35]. This index typically contains elements of both direct and indirect selection. It not only uses information on the selection candidates, but it also uses information on the genetic parameters and assumed economic weights for different breeding-goal traits in order to arrive at appropriate index weights. The genetic parameters include the genetic and non-genetic variances 
that determine the heritabilities of individual traits, and corresponding between-trait covariances that contribute to genetic and non-genetic correlations. Given good information on the genetic parameters and on the comparative economic worth of genetic changes in breeding-goal traits, it is in principle possible to optimise the comparative emphasis on selection traits. Also, one can in principle predict, for a given intensity of selection, genetic gains in various traits and the aggregate value of the genetic gains. In practice, the tree breeder faces much uncertainty about genetic parameter values and economic-worth functions. Genetic correlations are often estimated very imprecisely, and can be appreciably site-specific, while comparative economic weights among breeding-goal traits can be very uncertain [36]. Especially troublesome is a combination of adverse between-trait genetic correlations and very uncertain economic-worth functions for individual traits; this can even mean genetic 'gains' that are of negative financial worth. (In practice, real gains will tend to be less than predicted ones because selection is always based on imperfect information on inheritance of traits). Table 3 summarises for some individual traits in radiata pine typical heritability values, coefficients of variation, general economic importance, and status in the breeding programme. Table 4 shows the general pattern of some between-trait genetic correlations for radiata pine in New Zealand. In addition, certain wood properties that show progressions which are largely but incompletely in step from pith to bark seem to be essentially uncorrelated genetically, e.g., density, fibre length and microfibril angle. These very imperfect genetic inter-correlations among wood properties (Table 4) complicate the task of genetic selection to push wood properties along the corewood-to-outerwood scale.

Table 3. General importance, status in breeding programme, and indicative information on variation and heritability for some individual traits in radiata pine (mainly after [8] Table 5.5, [20,37,38]).

\begin{tabular}{lcccc}
\hline \multicolumn{1}{c}{ Trait } & $\begin{array}{c}\text { Economic } \\
\text { Importance }\end{array}$ & Status & $\begin{array}{c}\text { Coefficient of } \\
\text { Variation (\%) }\end{array}$ & Heritability \\
\hline Height & High & No & 12 & $\sim 0.2$ \\
Stem diameter & Very high & Sel & 15 & $\sim 0.2$ \\
Stem volume & Very high & BG & 30 & $\sim 0.2$ \\
Branch frequency & High indirect & sel & $20-30$ & 0.45 \\
Branch size & High & Inc & - & 0.2 \\
Branch angle & High & & - & 0.2 \\
Malformation & High negative & BG & - & $0.05-0.1$ \\
Wood density & Can be high & & & \\
$\quad$ Cores/discs & Can be high & Sp & & 0.6 \\
$\quad$ Indirect measure & Can be high & Sel & & $0.3-0.4$ \\
Fibre length & Now low & No & 10 & $>0.5$ \\
Wood stiffness & Very high & BG & 0.5 & 0.6 \\
$\quad$ Acoustic velocity & Indirect & Sel & 10 & 0.4 \\
$\quad$ Microfibril angle & Indirect & Inc & 10 & $\sim 0.6$ \\
Grain spirality & Significant & Sp & $>50$ & $0.2-0.5 ?$ \\
Wood collapse & High negative & Sp & $\sim 40$ & 0.2 \\
Longitudinal shrinkage (-ve) & High negative & Sp & $\sim 40$ & 0.3 \\
\hline
\end{tabular}

${ }^{1}$ BG denotes key breeding-goal trait: Sel-Key selection trait for indirect breeding-goal selection; Inc-often addressed incidentally by selection trait(s); Sp-addressed in specific situations; No-not generally addressed directly to date in breeding. ${ }^{2}$ Tree-to-tree, if there is a meaningful measure. ? denote significant uncertainty.

The selection index is by no means the only method for multi-trait selection [6] (pp. 352-354), [30]; indeed, some other methods (e.g., sequential culling for successive traits within a generation) can be more cost-efficient given differences among traits in assay costs and the ages at which phenotypic information comes available. However, the index provides a valuable framework for exploring the sensitivity of financial gain to variations in uncertain genetic parameters and in assumed and real economic-worth functions. 
Table 4. Approximate pattern, in terms of sign and strength, of genetic correlations between traits in radiata pine.

\begin{tabular}{|c|c|c|c|c|c|c|c|c|c|}
\hline & HT & DIAM & BRF & IL & BDA & TF & DEN & STF & STA \\
\hline Height (HT) & 1 & & & & & & & & \\
\hline Stem diameter (DIAM) & +++ & 1 & & & & & & & \\
\hline Branching frequency (BRF) & $+^{*}$ & $++*$ & 1 & & & & & & \\
\hline Internode length (IL) & $(-)$ & $(-)$ & $(-)$ & 1 & & & & & \\
\hline Branch diam./angle (BDA) & - & + & ++ & $(-)$ & 1 & & & & \\
\hline General tree form/defect size (TF) & + & + & + & $(-)^{*}$ & ++ & 1 & & & \\
\hline Wood density (DEN) & - & - & 0 & $(0)$ & 0 & 0 & 1 & & \\
\hline Wood stiffness (STF) & $(-)$ & - & 0 & $(0)$ & 0 & 0 & ++ & 1 & \\
\hline Dimensional stability/Drying degrade (STA) & $(-)$ & $(-)$ & (0) & $(0)$ & $(-)$ & (0) & $(0)$ & $(++)$ & 1 \\
\hline
\end{tabular}

* Much less pronounced on slower-growth sites. Plus signs (+) denote positive or favourable correlations, minus signs (-) negative or adverse correlations number of signs roughly denoting strength of correlation, 0 roughly neutral. Adapted from Burdon [37], Wu et al. [20] and Burdon et al. ([8] Table 7.5). Parentheses indicate evidence is indirect or sketchy.

Among wood properties, performance-related ones, which are primarily stiffness, dimensional stability and appearance, merit actual economic weights, rather than the underlying basic physical, anatomical and chemical properties. Also, corewood properties may warrant greater economic weights, despite being expressed most in young trees, because they tend to be more limiting for utilisation. However, genetic improvement of corewood stiffness is complicated by the fact that it is governed substantially by microfibril angle as well as by density, unlike outerwood stiffness which is governed pre-eminently by density $[39,40]$.

\subsection{Genetic Trade-Offs}

Trade-offs between genetic gains achievable in different traits are the rule rather than the exception, typically between growth rate, on the one hand, and various wood properties, on the other. Where there are adverse genetic correlations between traits ('hard' genetic trade-offs) the trade-offs can be very severe; indeed, they can severely limit the feasible multi-trait breeding goals. Indeed, adverse genetic correlations between stem diameter (effectively the main component of individual-tree volume) and wood properties are almost pervasive in radiata pine (see review by Wu et al. [23,41]). The wood properties involved include basic density, stiffness (or its determinants), susceptibility to internal checking, and almost certainly various aspects of dimensional stability. Admittedly, such adverse genetic correlations are always imperfect, so one can choose favourable deviants from such correlations, so-called "correlation breakers", allowing simultaneous genetic gains to be achieved in both growth rate and wood quality. Indeed, genetic gains for wood density have been achieved in recent years with radiata pine [42] alongside continuing genetic gains for the growth rate. Nevertheless, the gains in growth rate from such simultaneous selection will be less than those from selecting for growth rate alone.

The effects of adverse genetic correlations between growth rate and wood-quality traits can be exacerbated by the strong trend toward better wood quality as the trees get older. This can arise from genetic gains in growth rate allowing reduced harvest ages, through log-size specifications being met earlier, but at a cost in reduced wood quality [10]. However, the impact of genetic gain for growth rate on the age of meeting log-size specifications appears not to have been quantified. However, it may well be much less than the corresponding impacts of spacing and/or of elevated soil fertility (see later) on the age, and certainly much less than many effects of major site differences. Comparing the magnitudes of these effects will be complicated by how genetic improvement in tree form often allows acceptable tree form under stocking and fertility levels that much accelerate diameter growth $[7,8]$.

Quantifying the practical import of the genetic trade-offs between growth rate and wood density - a key component of wood quality, especially outside the corewood and juvenile wood (sensu novo [12,43]) zones [36,40,43]—is of major interest. Published results, however, almost all relate to the relationships among individual trees, early in the rotation, whereas the real, practical interest 
lies in how the trade-off plays out for the whole crop at harvest age. Given the competitive interactions among individual, genetically differing trees, and the pattern of genetic inter-correlations involving wood density, tree height and tree diameter [44-46], the genetic trade-off at harvest age between wood density and volume production could well be stronger at the whole-crop level than it is for young, individual trees [30]. While quantifying such a trade-off is very challenging technically, it would certainly be needed for appropriate assignment of comparative selection weights to different traits in multi-trait selection. Specifically, it requires quantifying the genotypic variance for contribution to whole-crop yield and its covariance(s) with some earlier, measured growth variable(s). While Evison and Apiolaza [36] addressed such covariance(s), they had no real basis for quantifying the key variance.

The projections of Carson et al. [47] to later ages of observed genetic gain in large-plot genetic gain trials with radiata pine, while not relating specifically to this question, are encouraging, although they have the important limitation of not addressing the trade-off between wood density and stem volume production. Much less encouraging, however, are the results of Vergara et al. [48] with slash pine and Stanger et al. [49] with eucalyptus hybrid clones. These indicated that the genetic variance for whole-crop productivity, as distinct from competitive ability, was actually very low.

Concerns have arisen that genetic improvement of some wood properties, notably spiral grain [50,51], might compromise mechanical performance of trees in resisting applied loads. However, such adverse side-effects would seem unlikely where genetic selection is used to counter downside effects of site or silviculture on the wood properties [30].

In addition to genetic trade-offs between productivity and wood properties are potential trade-offs between growth potential and 'defensive' attributes [52]. Prominent among the defences in forest trees are climatic tolerances and resistance to or tolerance of diseases or pests. In radiata pine, however, there are likely exceptions to the classical trade-offs; its very fast growth can help it escape frosty, ground-level microclimates, or facilitate rapid recovery from shoot dieback or defoliation. However, a classical trade-off may involve the production of heartwood and its extractives content. Heartwood and high extractives content are both undesirable for high-value appearance-grade products, while heartwood incidence is appreciably heritable [53] and its extractives content highly so [54]. Heartwood extractives have a very high energy content, which does not go into producing cellulose. However, there is a likely cost, in defences against diseases or pests, of selective breeding for less heartwood and extractives.

The best known between-trait trade-offs in radiata pine do not actually involve basic wood properties as such. With the extreme and complex variability in branching pattern [55,56], with at least some components strongly heritable [57-59], branching pattern has figured prominently in selective breeding. Key trade-offs $[8,60]$ involve length of clearcuttings obtainable between knot clusters without pruning and size of knots where they occur, and between the clearcutting lengths and both growth rate and quality of tree form on fertile, high-index sites. To address this trade-off a special Long Internode breed of radiata pine was pursued as an alternative to the mainstream 'short-internode' (Growth and Form) breed, but without commercial uptake [60]. Genetic correlations between branching habit variables and basic wood properties, however, seem negligible (Table 4).

\subsection{Impacts of New Selection Technology?}

Genetic selection has been progressively refined, by more sophisticated algorithms for using phenotypic information on not only the selection candidates but also their relatives ([6] Chapter 15). The phenotypic information originally represented field measurement data combined with visual ratings, but has become increasingly supplemented by laboratory-based determinations. Nowadays there is increasing pursuit of genomic selection, based upon whole-genome scans [61-63], which can allow provisional evaluation of candidate genotypes in advance of phenotypic information. Other genomic applications, which include pedigree analysis [64], will doubtless be useful for radiata pine breeding. In addition, remote-sensing technologies offer the prospect of obtaining very large volumes of field phenotypic data at modest cost $[65,66]$. However, such developments do not really 
alter the challenges posed by the genetic trade-offs between productivity and quality-related traits [47]. There is some prospect, though, of genomic selection offering earlier and better identification of so-called correlation breakers (cf. [67]).

\section{Silvicultural Interventions}

These include nursery systems, site preparation (which may include cultivation, drainage, and control of competing vegetation before and soon after planting), fertiliser use, control of growing space, tending and choice of harvest age $[5,68]$. Nursery systems, site preparation and weed control, and initial fertiliser applications, being parts of the basic prerequisite of good establishment, are not considered further. Similarly, we do not consider pruning which is mostly focussed on improving $\log$ quality through removal of branches, in order to eliminate knots, rather than on affecting internal wood properties. Accordingly, our focus is on boosting soil fertility during the main period of stand growth, manipulation of stocking, and the impacts of reducing harvest age.

The impacts of silvicultural interventions on wood quality-indeed, more generally on quality-related traits-in radiata pine are quite well understood in qualitative terms [17,69]. However, quantifying the detailed relationships is challenging, and doubtless hampered by the fact that the quantitative relationships can be specific to individual situations (e.g., [70-74]), so it has generally not been achieved. But one can safely say that the impacts are often large, involving some highly adverse effects of interventions that boost site productivity and/or reduce harvest age. The negative effects tend to be accompanied by exaggerated expression of genetic variation in traits, in what is termed level-of-expression (LoE) genotype-environment interaction [17,75]. Incidentally, for traits that must be assayed by visual scores rather than in absolute values, genetic gain predictions in the presence of LoE interaction may best be made by varying economic weights according to LoE [75]. Overall, despite large gaps in quantitative data, the general implications of silvicultural impacts on wood quality for tree breeding are clear.

\subsection{Boosting Site Productivity through Fertiliser Treatment}

For increasing productivity by non-genetic means, a key intervention is raising site productivity through improving soil fertility. In radiata pine phosphorus deficiency has been regionally severe [76], but it is readily and routinely corrected $[8,77,78]$. Other nutrient deficiencies (e.g., zinc in parts of Australia and manganese in parts of South Africa) have been identified and easily corrected, to.make the difference between being able or unable to grow radiata pine commercially [8]. However, the nutrient that is very often limiting but not acutely deficient, and often dominates soil fertility, is nitrogen. Site productivity of radiata pine in New Zealand is strongly associated with the ratio of carbon to nitrogen in the soil $[79,80]$. There are tantalising indications of much greater scope for boosting productivity in radiata pine by increasing nitrogen availability than has been indicated by the results [81,82] of historic fertiliser experiments.

A complication arises in the role of the soil microbiota, including mycorrhizal fungi and bacteria, in governing nutrient availability and general vigour of trees. In radiata pine there have seldom been problems with lack of mycorrhizal symbionts. Far less understood, however, and beyond the scope of this paper, are the prospects of actively manipulating carbon forms and the microbial symbionts to optimize tree growth.

The scope for such a major boost in productivity by manipulating soil fertility is suggested by the 'farm site effect' observed in New Zealand, with yields of radiata pine being $20-40 \%$ higher on ex-pasture sites with elevated soil fertility [83] compared with sites that had carried forest or shrubby vegetation. Such levels of productivity generally much exceed those achieved in fertiliser trials on forest sites [81,82]. The reasons for the full farm site affect are unclear, although they presumably involve the soil microbiota and soil carbon forms. But whatever the causes of this effect, its magnitude creates a strong incentive to find whether it is possible to mimic it and how to do so sustainably, provided its ill-effects on tree form and wood properties can be minimised or offset. The evidence 
suggests that the farm site effect on productivity declines percentagewise with stand age. Maclaren and Knowles [84] calculated a decline in the boost in predicted stem volume production from 33\% at age 21 to only 13\% at age 31, on a farm site that "was not extremely fertile" [85]. Aside from possible estimation errors, it is not ascertained how much this decline resulted from a 'wearing-off' of the elevated soil fertility or was an effect of the architecture of crop development on the impact of elevated soil fertility at different stand ages on stemwood volume production.

While increases in productivity resulting from boosted soil fertility can be major, they tend to be at the expense of wood properties [86] and other quality-related traits such as stem straightness, knot size and freedom from malformation [17]. Indeed, there is good reason to believe that such fertility would be associated with more reaction wood [87], much reduced stiffness [81,84], and poorer dimensional stability, and more internal checking [88,89]. Such soil fertility also adversely affects tree-form traits, further accentuating the importance of quality-related genetic selection criteria. Moreover, all these quality-related traits are notoriously degraded by exposure on fertile sites, creating even more call for genetic selection to defend wood quality.

The evidence reviewed by Maclaren [88] was largely unpublished, but was plentiful although largely qualitative. However, the broader quantitative relationships, between the boost in productivity from achieving or mimicking the farm site effect and its adverse effects on wood properties, remain exasperatingly unclear. Unfortunately, there has been little research into the wood quality of radiata pine on farm sites, which could yield the best quantitative information on effects of high fertility on wood properties. Many of the stands were planted on fertile ex-farm sites in the early 1990s, so there is still the opportunity, albeit brief, to obtain quantitative information on the wood quality in these stands before they are harvested.

These adverse effects of fertility-boosted productivity on quality-related traits strengthens the call for greater emphasis on genetic selection for quality traits. For defending or even improving wood-quality traits, the adverse genetic correlations ('hard' genetic trade-offs) mean that the scope for genetic selection for growth rate will thus be further compromised. Even with quality-related traits that are neutrally correlated genetically with growth rate, as some tree-form traits evidently are (Table 2), a 'soft' trade-off may arise because the requisite additional selection emphasis on such traits will cause greater dilution of genetic gains for growth rate through multi-trait selection. (Actually, if all traits of interest are of equal heritability and economic importance, greater aggregate genetic gain can be expected from selecting for all of them simultaneously [90,91], but the conditions for this are seldom if ever met.) The trade-offs will likely be accentuated by the fact that the 'corewood syndrome' involves several wood properties [10], so really effective genetic improvement of corewood may entail simultaneous selection for several wood properties that are inherited in some degree independently. Because of the trade-offs the selection effort needs to focus on a small number of the most important breeding-goal traits. However, tree breeders will add some light culling for 'non-key traits' (e.g., external resin bleeding, internal checking, heartwood characteristics) $[15,16]$ which may be expressed in only a minority of genotypes.

\subsection{Stocking Control}

Key aspects of stocking control are the choice of initial planting density and the timing and severity of thinning operations. However, in this paper we only address the broad impacts of level of stocking, accepting that there may be specific impacts of factors such as severity of thinning. New Zealand has had vivid experiences of the effects of stocking in radiata pine. The Direct Sawlog thinning and pruning regime proposed by Fenton and Sutton [92] was very widely adopted by forest managers from around 1970 onwards [8]. This regime entailed some sacrifice in productivity through pre-commercial thinning to relatively low stand densities that favoured rapid clearwood production on pruned butt logs and reduced harvest age. However, the sacrifice in productivity and basic wood properties has proved greater than originally expected, which has severely impacted on the profitability of such a regime in situations when the premiums for large-diameter pruned logs are not sufficiently large. 
Nor is the situation helped when knots are larger than anticipated in the 'second' log, immediately above the pruned butt log. Indeed, it is now clear that relatively high post-thinning stand densities (400 or more stems/ha) are needed to maximise productivity and financial returns at harvest in radiata pine [93-95]. However, stocking levels that purely maximize productivity [95] are liable to lower crop value by reducing piece sizes and possibly recoverable volume of wood.

Low stocking strongly favours individual-tree diameter growth and thus earlier attainment of target log-size specifications. However, it can militate strongly against wood quality in both increasing percentage of corewood and having more direct effects on wood-quality components, an exception being that low stocking allows the benefits of pruning to be fully realised. Also, by reducing productivity, low stocking levels will tend to reduce carbon sequestration, although insofar as they allow earlier harvests they bring forward the dates of carbon sequestration through wood in service. Low stocking, along with elevated site fertility, not only tends to depress wood quality [74], but it can also inflate the expression of among-tree genetic variation in quality-related traits [17]. Also, the adverse effects on productivity of low stocking can increase the size and severity of timber defects through ill-effects on tree form. As mentioned earlier, a notorious but largely undocumented effect is the disastrous form of trees with the long-internode branching habit on sites that are both exposed and highly fertile $[25,96,97]$. In such situations the productivity gains resulting from the fertility can be eroded by increased logging waste caused by stem malformation.

The impacts of high stocking on various aspects of wood quality, however, are more complicated, and may vary according to local conditions. High stocking has been repeatedly associated with higher wood stiffness (modulus of elasticity), largely independent of effects on corewood percent [71,97,98]. Despite enhancing wood stiffness, high stocking can lead to higher percentages of corewood, although such effects on corewood percent seem generally minor [88,99]. Overall, the results of Cown and Dowling [100] strongly indicate that the benefits of higher stocking on wood stiffness outweigh any downside in outerwood percentage. That said, higher stocking will tend to reduce piece size and the thickness of clearwood zones achievable by pruning. Both the overall piece size and the relative volume of clearwood affect the recovery of clear lumber in a mill [101].

\subsection{Length of Rotation}

Economic attractions can exist for harvesting even before the culmination of mean annual increment, although they may be less for the forest estate than for individual stands. For most wood properties and end-products longer rotations are advantageous in radiata pine [102], except when they incur excessive heartwood [53]. (Heartwood in radiata pine is neither reliably durable nor reliably treatable with preservative, and often adversely affects appearance.) Some ulterior justification for longer rotations can arise in increased carbon sequestration [103]. However, shorter rotations are typically very prejudicial for wood properties, leading to greatly increased corewood proportions.

\subsection{Maturation Effects}

There is some possible scope for defending tree form significantly by deploying propagules with some maturation ('physiological ageing') [104]. Some maturation may also help defend some wood properties, through reductions in microfibril angle and compression wood incidence, which should mitigate longitudinal shrinkage and help maintain stiffness, but would tend to accentuate spiral grain angle $[9,43,104]$. However, too much maturation makes mass-propagation too difficult and expensive, and reduces vigour in successfully rooted propagules. Exploiting the advantages of maturation formed part of a proposal to institute a 'Farm Site' breed of radiata pine [29] which, however, did not get implemented.

A relatively subtle effect of harvest age arises in addition to effects of maturation state of the planted propagules. It does so because wood properties in relation to ring number from the pith can vary with height from the ground [9], according to how maturation state increases with height. With very short rotations, the proportion of juvenile wood (sensu novo) $[9,43]$, which occurs close 
to ground level, might be appreciably elevated. This could contribute further loss of in stiffness, and possibly poorer dimensional stability, but a lower spiral grain angle and lower fibre coarseness.

\subsection{Combined Effects and Synergisms}

The effects of site and silviculture can be strongly reinforcing, even synergistic, although such effects may be very case-specific. The pathways for the effects on wood properties (Table 5) are various. Both elevated fertility and lower stocking levels can undoubtedly have very adverse effects on tree form (affecting knot sizes and grain distortion), wood stiffness (through more reaction wood and more directly), and dimensional stability in drying and in service (also through more reaction wood and more directly). These effects reinforce the adverse effects of the reductions in harvest age that they can bring. Importantly, the adverse effects of silviculture on wood quality appear to be generally accompanied by heightened expression of genetic variation in quality-related traits. Indeed, the effects of genetics and silviculture may be synergistic, representing second-order level-of-expression interaction among genotype, site and silviculture as specified by Burdon et al. [17]. Anyway, the heightened need to defend wood quality in the presence of joint influences is fortunately accompanied by the enhanced scope for genetic selection to defend it.

Table 5. Putative importance in adverse effects of main interventions on wood of alternative pathways of influence for radiata pine.

\begin{tabular}{clc}
\hline \multicolumn{1}{c}{ Intervention } & \multicolumn{1}{c}{ Pathway } & Effect(s) \\
\hline \multirow{5}{*}{ Selection for growth rate } & $\begin{array}{l}\text { 1. Direct (correlated selection response) } \\
\text { 2. Via effects on tree form } \\
\text { 3. Via corewood \% } \\
\text { 4. Via earlier harvest via increased corewood \% }\end{array}$ & $\begin{array}{c}\text { Strong, almost across board } \\
\text { Usually favourable } \\
\text { Uncertain }\end{array}$ \\
& 1. Direct & Some, not quantified \\
\hline \multirow{5}{*}{ Reduced stocking } & 2. Via effects on tree form & Strong on stiffness \\
& 3. Via corewood \% & Strong on some sites \\
& 4. Via earlier harvest via increased corewood \% & Strong, almost across board \\
\hline & 1. Direct & Strong \\
& 2. Via effects on tree form & Strong \\
3. Via corewood \% & Uncertain \\
& 4. Via earlier harvest via increased corewood \% & Strong \\
\hline
\end{tabular}

\section{The Future Technological Context?}

The topic is addressed essentially in the context of the current level of domestication of radiata pine. For the longer term, there are ways in which domestication might be much intensified [8]. For instance, it is likely that net productivity can be lifted by conferring reproductive sterility. This would also remove an important objection to the use of either genetic engineering through effectively containing transgenes or any other DNA sequences or combinations involved in creating Genetically Modified Organisms. However, new technology for genetic manipulation and propagation systems, while it may provide more powerful tools, is not seen as fundamentally changing the issues surrounding the corewood phenomenon in conjunction with the pressures to grow short-rotation forest plantation crops.

As mentioned earlier, the context of genomic selection may facilitate selection of 'correlation breakers' (strongly favourable deviants from adverse genetic correlations) by identifying genomic regions where pleiotropic effects are minimal. However, the consistency of between-trait genetic correlations across all populations of radiata pine [72] indicates that the genetic correlations predominantly reflect pleiotropy rather than just the chromosomal linkage that is more readily overcome. 


\section{Possible Implications for Other Tree Species}

We have considered radiata pine as a 'benchmark' case for two reasons, (1) the extensive knowledge base that we already have concerning genetic parameters and the behaviour of wood properties, even though various important quantitative relationships remain to be quantified; and (2) the importance of the corewood phenomenon which involves several key wood properties and a high proportion of the wood in crops grown on economic rotations. Thus, the issues are writ very large for radiata pine. Looking to other species, the extremely important loblolly pine (Pinus taeda L.) has some very similar wood-quality issues to radiata pine [9,105]. Other fast-growing tropical and subtropical pines are likely to share both the nature of the corewood phenomenon and its high percentage in harvested wood. Going to other temperate pines, and other genera, the corewood phenomenon may often be less important, involving some wood properties less and representing smaller proportions of the wood yield [106]. For instance, Douglas-fir (Pseudotsuga menziesii Mirb. Franco) shows less [69,107] and cypresses (Cupressus spp., Chamaecyparis spp.) much less [108,109] pith-to-bark progression of wood density than radiata pine does, although they may show similar progressions in microfibril angle, wood stiffness, and fibre length. In the Cupressaceae/Taxodiaceae complex, including cypresses and coast redwood (Sequoia sempervirens D.Don Endl.), in which durable heartwood is desirable, young trees often have disappointing heartwood durability $[110,111]$. Outside conifers, this has also been observed in several eucalypt species [112], and evidently in teak (Tectona grandis L. f.) [113].

\section{Conclusions}

The emphasis has been on needs for structural, solid-wood products, which include plywood and laminated products as well as conventional lumber. These products are of key importance in the utilisation of radiata pine wood, and are subject to consistent influences from adverse genetic correlations with growth-rate variables and various effects of intensive silvicultural practices. The effects on wood properties and their putative pathways of action, which are summarised in Table 5, apply primarily to solid-wood products. With appearance-grade products, which can command quite high prices, the situation is more complicated. For them, some adverse genetic correlations are involved with branching habit and growth rate, but mechanical stiffness is not crucial, although dimensional stability is important and subject to some of the same influences as stiffness. The implications for productivity and product quality in relation to stocking and harvest age are also more complicated. The effects on wood properties, and their putative pathways of influence, apply primarily to solid-wood products. While a significant portion of the crop is pulpwood, going into pulps and reconstituted wood for which corewood can have some advantages, pulpwood in New Zealand is quite a minor proportion of the radiata pine crop and fetches essentially by-product prices.

Adverse genetic correlations between wood properties and stem volume production appear to be almost pervasive in radiata pine. They, therefore, limit the genetic gain that is simultaneously achievable on both fronts, requiring proactive selection even to defend against drops in wood quality. At the same time, some key influences of silvicultural measures to boost productivity and reduce harvest age are highly prejudicial to wood quality, through both increasing the corewood percentage and other, more direct effects on some wood properties. The combined effects of adverse genetic correlations and net silvicultural influences place the tree breeder under heavy pressure to pursue genetic improvement in wood properties, even at the expense of considerable potential genetic gain in productivity. The breeder's work will need to be complemented by judicious deployment of improved breeds or clones to sites and silvicultural regimes.

While our focus has been on radiata pine, similar but not identical needs are likely for various other species that are grown on short rotations.

Author Contributions: R.D.B. drafted the manuscript, J.R.M. contributed revision, and both contributed to final preparation. 
Funding: Funding support for J.R.M. came from the New Zealand Ministry for Business, Innovation and Employment (C04X1306) and the Forest Growers' Levy Trust as part of the Growing Confidence in Forestry's Future research programme.

Acknowledgments: We thank Emily Telfer and Heidi Dungey for reading the manuscript and providing various references. Scion provided office facilities for RDB. Suggestions from anonymous reviewers concerning presentation are also acknowledged.

Conflicts of Interest: The authors declare no conflict of interest.

\section{References}

1. Sutton, W.R.J. The need for planted forests and the example of radiata pine. New For. 1999, 17, 95-110. [CrossRef]

2. Carle, J.; Holmgren, P. Wood from planted forests: A global outlook 2005-2030. For. Prod. J. 2008, 58, 6-18.

3. Klemperer, W.D. Forest Resource Economics and Finance; McGraw-Hill: New York, NY, USA, 1996; p. 551.

4. Powers, R.F. On the sustainable productivity of planted forests. New For. 1999, 17, 263-306. [CrossRef]

5. Fox, T.R. Sustained productivity in intensively managed forest plantations. For. Ecol. Manag. 2000, 138, 187-202. [CrossRef]

6. White, T.L.; Adams, W.T.; Neale, D.B. Forest Genetics; CABI Publishing: Wallingford, UK; Cambridge, MA, USA, 2007; p. 682.

7. Burdon, R.D.; Carson, M.J.; Shelbourne, C.J.A. Achievements in forest tree genetic improvement in Australia and New Zealand 10: Pinus radiata in New Zealand. Aust. For. 2008, 71, 263-279. [CrossRef]

8. Burdon, R.D.; Libby, W.J.; Brown, A.G. Domestication of Radiata Pine; Springer International Publishing AG: Cham, Switzerland, 2017; p. xxxv-480.

9. Burdon, R.D.; Kibblewhite, R.P.; Walker, J.C.F.; Megraw, R.A.; Evans, R.; Cown, D.J. Juvenile versus mature wood: A new concept, orthogonal to corewood versus outerwood, with special reference to Pinus radiata and P. taeda. For. Sci. 2004, 50, 399-415.

10. Moore, J.R.; Cown, D.J. Corewood (juvenile wood) and its impact on wood utilisation. Curr. For. Rep. 2017, 3, 107-118. [CrossRef]

11. Moore, J.R.; Cown, D.J.; McKinley, R.B. Modelling microfibril angle variation in New Zealand-grown radiata pine. N. Z. J. For. Sci. 2014, 44, 25. [CrossRef]

12. Kimberley, M.O.; Cown, D.J.; McKinley, R.B.; Moore, J.R.; Dowling, L.J. Modelling variation in wood density within and among trees in stands of New Zealand-grown radiata pine. N. Z. J. For. Sci. 2015, 45, 22. [CrossRef]

13. Moore, J.R.; Cown, D.J.; McKinley, R.B. Modelling spiral grain angle variation in New Zealand-grown radiata pine. N. Z. J. For. Sci. 2015, 45, 15. [CrossRef]

14. Savidge, R.A. Tree growth and wood quality. In Wood Quality and Its Biological Basis; Barnett, J.R., Jeronimidis, G., Eds.; Blackwell Publishing: Oxford, UK, 2003; pp. 1-29.

15. Kumar, S. Genetic parameter estimates for wood stiffness, internal checking, and resin bleeding in radiata pine. Can. J. For. Res. 2004, 34, 2601-2610. [CrossRef]

16. Li, Y.; Dungey, H.; Yanchuk, A.; Apiolaza, L.A. Improvement of non-key traits in radiata pine breeding programme when long-term economic importance is uncertain. PLOS ONE 2017, 12, e0177806. [CrossRef] [PubMed]

17. Burdon, R.D.; Li, Y.; Suontama, M.; Dungey, H.S. Genotype $\times$ site $\times$ silviculture interactions in radiata pine: Knowledge, working hypotheses and pointers for research. N. Z. J. For. Sci. 2017, 47, 6. [CrossRef]

18. Kimberley, M.O.; Moore, J.; Dungey, H.S. Quantification of realised genetic gain in radiata pine and its incorporation into growth and yield modelling systems. Can. J. For. Res. 2015, 1676-1687. [CrossRef]

19. Carson, S.D. Selecting Pinus radiata for resistance to Dothistroma needle blight. N. Z. J. For. Sci. 1989, $19,3-21$.

20. Suontama, M.; Low, C.B.; Li, Y.; Dungey, H.S. Breeding for improved resistance to Cyclaneusma needle cast in Pinus radiata in New Zealand. Manuscript in preparation, 2018.

21. Dungey, H.S.; Williams, N.M.; Low, C.B.; Stovold, G.T. First evidence of genetic-based tolerance to red needle cast caused by Phytophthora pluvialis in radiata pine. N. Z. J. For. Sci. 2014, 44, 31. [CrossRef] 
22. Graham, N.J.; Suontama, M.; Li, Y.; Bader, M.K.; Dungey, H.S.; Williams, N.M. Establishing a screening strategy to assess genetic variation of resistance to red needle cast in a Pinus radiata breeding population. Manuscript in preparation, 2018.

23. Wu, H.X.; Ivković, M.; Gapare, W.J.; Matheson, A.C.; Baltunis, B.S.; Powell, M.B.; McRae, T.A. Breeding for wood quality and profit in Pinus radiata: A review of genetic parameter estimates and implications for breeding and deployment. N. Z. J. For. Sci. 2008, 38, 56-87.

24. Watt, M.S.; Sorensson, C.; Cown, D.J.; Dungey, H.S.; Evans, R. Determining the main and interactive effect of age and clone on wood density, microfibril angle and modulus of elasticity for Pinus radiata. Can. J. For. Res. 2010, 40, 1550-1557. [CrossRef]

25. Baltunis, B.S.; Wu, H.X.; Powell, M.B. Inheritance of density, microfibril angle, and modulus of elasticity in juvenile wood of Pinus radiata at two locations in Australia. Can. J. For. Res. 2007, 37, 2167-2174. [CrossRef]

26. Gapare, W.J.; Ivković, M.; Baltunis, B.S.; Matheson, A.C.; Wu, H.X. Genetic stability of wood density and diameter in Pinus radiata D. Don plantation estate across Australia. Tree Genet. Genomes 2009, 6, 113-125. [CrossRef]

27. Baltunis, B.S.; Gapare, W.J.; Wu, H.X. Genetic parameters and genotype by environment interaction in radiata pine for growth and wood quality traits in Australia. Silvae Genet. 2010, 59, 113-124. [CrossRef]

28. Burdon, R.D.; Britton, R.A.J.; Walford, G.B. Wood stiffness and bending strength in relation to density in four native provenances of Pinus radiata. N. Z. J. For. Sci. 2001, 31, 130-146.

29. Jayawickrama, K.J.S.; Carson, M.J. A breeding strategy for the New Zealand Radiata Pine Breeding Cooperative. Silvae Genet. 2000, 49, 82-90.

30. Burdon, R.D. Wood properties and genetic improvement of radiata pine. N. Z. J. For. 2010, 55, $22-27$.

31. Cown, D.J. Corewood (juvenile wood) in Pinus radiata-Should we be concerned? N. Z. J. For. Sci. 1992, 22, 87-95.

32. Lindström, H.; Harris, P.; Nakada, R. Methods for measuring stiffness of young trees. Holz Roh Werkst. 2002, 60, 165-174. [CrossRef]

33. Evans, R. Silviscan and its future in wood quality assessment. In Proceedings of the 54th APPITA Annual General Conference, Melbourne, Australia, 3-6 April 2000; APPITA: Melbourne, Australia, 2000; pp. 271-274.

34. Jayawickrama, K.J.S. Breeding radiata pine for wood stiffness: Review and analysis. Aust. For. 2001, 64, 51-56. [CrossRef]

35. Cotterill, P.P.; Dean, C.A. Successful Tree Breeding with Index Selection; CSIRO Publications: East Melbourne, Australia, 1990; p. 80.

36. Evison, D.C.; Apiolaza, L.A. Incorporating economic weights into radiata pine breeding selection decisions. Can. J. For. Res. 2015, 45, 135-140. [CrossRef]

37. Burdon, R.D. Genetic survey of Pinus radiata. 9: General discussion and implications for genetic management. N. Z. J. For. Sci. 1992, 22, 274-298.

38. Kumar, S.; Burdon, R.D.; Stovold, G.T. Wood properties and stem diameter of Pinus radiata in New Zealand: Genetic parameter estimates of clonal and seedling material. N. Z. J. For. Sci. 2008, 38, 88-101.

39. Walker, J.C.F.; Butterfield, B. The importance of microfibril angle for the processing industries. N. Z. J. For. 1995, 40, 34-40.

40. Cown, D.J.; Hebert, J.; Ball, R. Modelling Pinus radiata lumber characteristics. Part 1: Mechanical properties of small clears. N. Z. J. For. Sci. 1999, 29, 203-213.

41. Gapare, W.J.; Baltunis, B.S.; Ivković, M.; Wu, H.X. Genetic correlations among juvenile wood quality and growth traits and implications for selection strategy in Pinus radiata D. Don. Ann. For. Sci. 2009, 66, 606. [CrossRef]

42. Kimberley, M.O.; Moore, J.R.; Dungey, H.S. Modelling the effects of genetic improvement on radiata pine wood density. N. Z. J. For. Sci. 2016, 46, 8. [CrossRef]

43. Burdon, R.; Walker, J.; Megraw, B.; Evans, R.; Cown, D. Juvenile wood (sensu novo) in pine: Conflicts and possible opportunities for growing, processing and utilisation. N. Z. J. For. 2004, 49, 24-31.

44. Burdon, R.D.; Harris, J.M. Wood density in radiata pine clones on four different sites. N. Z. J. For. Sci. 1973, 3, 286-303.

45. Bannister, M.H.; Vine, M.H. An early progeny trial in Pinus radiata. 4. Wood density. N. Z. J. For. Sci. 1981, 11, 221-243. 
46. Burdon, R.D.; Low, C.B. Genetic survey of Pinus radiata. 6. Wood properties: Variation, heritabilities, and interrelationships with other traits. N. Z. J. For. Sci. 1992, 22, 228-245.

47. Carson, S.D.; Garcia, O.; Hayes, J.D. Realized gain and prediction of yield with genetically improved Pinus radiata in New Zealand. For. Sci. 1999, 45, 186-200.

48. Vergara, R.; White, T.L.; Huber, D.A.; Shiver, B.D.; Rockwood, D.L. Estimated realized gains for first-generation slash pine (Pinus elliottii var. elliottii) tree improvement in the southeastern United States. Can. J. For. Res. 2004, 34, 2587-2600. [CrossRef]

49. Stanger, T.K.; Galloway, G.M.; Retief, E.C. Final results from a trial to test the effect of plot size on Eucalyptus hybrid clonal ranking in coastal Zululand, South Africa. South. For. J. For. Sci. 2011, 73, 131-135.

50. Kubler, H. Function of spiral grain in trees. Trees 1991, 5, 125-135. [CrossRef]

51. Skatter, S.; Kučera, B. Spiral grain-An adaptation of trees to withstand stem breakage caused by wind-induced torsion. Holz Roh Werkst. 1997, 55, 207-213. [CrossRef]

52. Loehle, C.; Namkoong, G. Discussion paper: Constraints on tree breeding: Growth tradeoffs, growth strategies, and defensive investments. For. Sci. 1987, 33, 1089-1097.

53. Kennedy, S.G.; Yanchuk, A.D.; Jefferson, P.A. Relationship of heartwood traits with diameter growth, implications for genetic selection in Pinus radiata. Tree Genet. Genomes 2013, 9, 1313-1319. [CrossRef]

54. Cown, D.J.; Young, G.D.; Burdon, R.D. Variation in wood characteristics of 20 year-old half-sib families of Pinus radiata. N. Z. J. For. Sci. 1992, 22, 63-76.

55. Bannister, M.H. Some variations in the growth pattern of Pinus radiata in New Zealand. N. Z. J. Sci. 1962, 5, 342-370.

56. Bannister, M.H. An early progeny trial in Pinus radiata. 3. Characters affecting log quality. N. Z. J. For. Sci. 1979, 9, 241-261.

57. Bannister, M.H. An early progeny trial in Pinus radiata. 2. Subjective assessment of crookedness. N. Z. J. For. Sci. 1980, 10, 325-342.

58. Burdon, R.D.; Bannister, M.H.; Low, C.B. Genetic survey of Pinus radiata. 3: Variance structures and narrow-sense heritability for growth variables and morphological traits in seedlings. N. Z. J. For. Sci. 1992, 22, 169-186.

59. Burdon, R.D.; Bannister, M.H.; Low, C.B. Genetic survey of Pinus radiata. 4: Variance structures and heritabilties in juvenile clones. N. Z. J. For. Sci. 1992, 22, 187-210.

60. Burdon, R.D. Branching habit in radiata pine-Breeding goals revisited. N. Z. J. For. 2008, 52, $20-23$.

61. Grattapaglia, D.; Resende, M.D.V. Genomic selection in forest tree breeding. Tree Genet. Genomes 2011, 241-255. [CrossRef]

62. Isik, F. Genomic selection in tree breeding: The concept and an outlook for the future. New For. 2014, 379-401. [CrossRef]

63. Plomion, C.; Bartholome, J.; Lesur, I.; Boury, C.; Rodriguez-Quilon, I.; Lagraulet, H.; Ehrenmann, F.; Bouffier, L.; Gion, J.M.; Grivet, D.; et al. High-density SNP assay development for genetic analysis in maritime pine (Pinus pinaster). Mol. Ecol. Resour. 2016, 16, 574-587. [CrossRef] [PubMed]

64. Klápštĕ, J.; Suontama, M.; Telfer, E.J.; Low, C.B.; Stovold, G.T.; McKinley, R.B.; Dungey, H.S. Exploration of genetic architecture through sib-ship reconstruction in advanced breeding population of Eucalyptus nitens. PLoS ONE 2017, 12, e0185137. [CrossRef] [PubMed]

65. Pont, D.; Watt, M.S.; Morgenroth, J.; Dungey, H.S. Correlating size, form, wood quality, and disease attributes with crown metrics from tree-based analysis of aerial LIDAR. Remote Sens. Environ. 2018, under review.

66. Pont, D.; Morgenroth, J.; Watt, M.S.; Dungey, H.S. Evaluation of ALS crown metrics for phenotyping size, form, wood quality, and disease traits in Pinus radiata trees in a genetics trial. Manuscript in preparation, 2018.

67. Klápště, J.; Telfer, E.; Macdonald, L.; Li, Y.; Graham, N.; Butcher, J.; Jefferson, P.; Hay, J.; Wilcox, P.; Cullis, B.; Dungey, H. Chasing for genetic correlation "breakers" to stimulate population resistance to climatic change. Manuscript in preparation, 2018.

68. Smith, D.M.; Larson, B.C.; Kelty, M.J.; Ashton, P.M.S. The Practice of Silviculture: Applied Forest Ecology, 9th ed.; John Wiley \& Sons: New York, NY, USA, 1997; p. 537.

69. Cown, D.J. New Zealand Pine and Douglas-fir: Suitability for Processing; Bulletin 216; New Zealand Forest Research Institute: Rotorua, New Zealand, 1999; p. 72.

70. Beets, P.N.; Gilchrist, K.; Jeffreys, M.P. Wood density of radiata pine: Effect of nitrogen supply. For. Ecol. Manag. 2001, 145, 173-180. [CrossRef] 
71. Lasserre, J.-P.; Mason, E.G.; Watt, M.S. The effects of genotype and spacing on Pinus radiata [D. Don] corewood stiffness in an 11-year old experiment. For. Ecol. Manag. 2005, 205, 375-383. [CrossRef]

72. Lasserre, J.P.; Mason, E.G.; Watt, M.S.; Moore, J.R. Influence of initial planting spacing and genotype on microfibril angle, wood density, fibre properties and modulus of elasticity in Pinus radiata D. Don corewood. For. Ecol. Manag. 2009, 258, 1924-1931. [CrossRef]

73. Watt, M.S.; Zoric, B.; Kimberley, M.O.; Harrington, J. Influence of stocking on radial and longitudinal variation in modulus of elasticity, microfibril angle, and density in a 24-year-old Pinus radiata thinning trial. Can. J. For. Res. 2011, 41, 1422-1431. [CrossRef]

74. Carson, S.D.; Cown, D.J.; McKinley, R.B.; Moore, J.R. Effects of site, silviculture and seedlot on wood density and estimated wood stiffness in radiata pine at mid-rotation. N. Z. J. For. Sci. 2014, 44, 26. [CrossRef]

75. Li, Y.; Suontama, M.; Burdon, R.D.; Dungey, H.S. Genotype by environment interactions in forest tree breeding: Review of methodology and perspectives on research and application. Tree Genet. Genomes 2017, 13, 60. [CrossRef]

76. Will, G.M. Nutrient deficiencies in Pinus radiata. N. Z. J. For. Sci. 1978, 8, 4-14.

77. Maclaren, J.P. Radiata Pine Grower's Manual; FRI Bulletin 184; New Zealand Forest Research Institute: Rotorua, New Zealand, 1993; p. 140.

78. Mead, D.J. Sustainable Management of Pinus Radiata Plantations; FAO: Rome, Italy, 2013; p. 246.

79. Watt, M.S.; Davis, M.R.; Clinton, P.W.; Coker, G.; Ross, C.; Dando, J.; Parfitt, R.L.; Simcock, R. Identification of key soil indicators influencing plantation productivity and sustainability across a national trial series in New Zealand. For. Ecol. Manag. 2008, 256, 180-190. [CrossRef]

80. Watt, M.S.; Palmer, D.J.; Kimberley, M.O.; Höck, B.K.; Payn, T.W.; Lowe, D.J. Development of models to predict Pinus radiata productivity throughout New Zealand. Can. J. For. Res. 2010, 40, 488-499. [CrossRef]

81. Hunter, I.R.; Graham, J.D.; Calvert, K.T. Effects of nitrogen on radiata pine growing on pumice soils. N. Z. J. For. 1985, 30, 102-114.

82. Smaill, S.J.; Clinton, P.W.; Höck, B.K. A nutrient balance model (NuBalM) to predict biomass and nitrogen pools in Pinus radiata forests. For. Ecol. Manag. 2011, 262, 270-277. [CrossRef]

83. Maclaren, J.P.; West, G.G. Farm site effect. In NZIF Forestry Handbook, 4th ed.; Colley, M., Ed.; New Zealand Institute of Forestry: Christchurch, New Zealand, 2005; pp. 76-77.

84. Maclaren, J.P.; Knowles, R.L. Economics of final crop stocking at the Tikitere agroforestry trial, part 1: Volume and quality comparisons. N. Z. J. For. Sci. 1999, 29, 165-174.

85. Maclaren, P. Internal Wood Quality of Radiata Pine on Farm Sites-A Review of the Issues; Forest and Farm Plantation Management Cooperative: Rotorua, New Zealand, 2002; p. 42.

86. Beets, P.N.; Kimberley, M.O.; McKinley, R.B. Predicting wood density of Pinus radiata annual growth increments. N. Z. J. For. Sci. 2007, 37, 241-266.

87. Burdon, R.D. Compression wood in Pinus radiata clones on four different sites. N. Z. J. For. Sci. 1975, 5, 152-164.

88. Maclaren, P. Internal wood quality of radiata pine on farm sites-A review of the issues. N. Z. J. For. 2002, $47,24-28$.

89. McConchie, D.L. Wood quality of radiata pine on farm sites. In Proceedings of the Wood Quality Workshop, Rotorua, New Zealand, 12 September 1997; Klitscher, K., Cown, D., Donaldson, L., Eds.; FRI Bulletin 202; Forest Research Institute: Rotorua, New Zealand, 1997; pp. 38-45.

90. Wright, J.W. Introduction to Forest Genetics; Academic Press: London, UK, 1976; p. 463.

91. Burdon, R.D. Quantitative genetic principles. In Encyclopedia of Forest Sciences; Burley, J., Evans, J., Youngquist, J.A., Eds.; Elsevier Academic Press: Oxford, UK; San Diego, CA, USA, 2004; Volume 1, pp. 181-187.

92. Fenton, R.T.; Sutton, W.R.J. Silvicultural proposals for radiata pine on high quality sites. N. Z. J. For. 1968, 13, 220-228.

93. Kimberley, M.; West, G.; Dean, M.; Knowles, L. The 300 index-A volume productivity index for radiata pine. N. Z. J. For. 2005, 50, 13-18.

94. Watt, M.S.; Kimberley, M.O.; Dash, J.; Harrison, D. Spatial prediction of optimal final stand density for even age plantation forests using productivity indices. Can. J. For. Res. 2016, 47, 527-535. [CrossRef] 
95. Moore, J.R.; Dash, J.P.; Lee, J.R.; McKinley, R.B.; Dungey, H.S. Quantifying the influence of seedlot and stand density on growth, wood properties and the economics of growing radiata pine. Forestry 2018, 97, 327-340. [CrossRef]

96. Carson, S.D.; Kimberley, M.O.; Hayes, J.D.; Carson, M.J. The effect of silviculture on genetic gain in growth of Pinus radiata at one-third rotation. Can. J. For. Res. 1999, 29, 1979-1984. [CrossRef]

97. Waghorn, M.J.; Mason, E.G.; Watt, M.S. Influence of initial stand density and genotype on longitudinal variation in modulus of elasticity for 17-year-old Pinus radiata. For. Ecol. Manag. 2007, 252, 67-72. [CrossRef]

98. Moore, J.R.; Cown, D.J.; McKinley, R.B.; Sabatia, C.O. Effects of stand density and seedlot on three wood properties of young radiata pine grown at a dry-land site in New Zealand. N. Z. J. For. Sci. 2015, 45, 4. [CrossRef]

99. West, G.G. Standpak evaluation of the effects of site, silviculture, and genetics on mean log age and the proportion of juvenile wood. N. Z. J. For. Sci. 1997, 27, 324-342.

100. Cown, D.; Dowling, L.J. Juvenile wood [sic] and its implications. N. Z. J. For. 2015, 59, 10-17.

101. Park, J. Pruned log index. N. Z. J. For. Sci. 1989, 19, 44-53.

102. Cown, D.J.; McConchie, D.L. Rotation age and silvicultural effects on wood properties of four stands of Pinus radiata. N. Z. J. For. Sci. 1982, 12, 71-85.

103. Manley, B.; Maclaren, P. Modelling the impact of carbon trading legislation on New Zealand's plantation estate. N. Z. J. For. 2009, 54, 39-44.

104. Menzies, M.I.; Faulds, T.; Holden, D.G.; Kumar, S.; Klomp, B.K. Maturation status and genetic improvement effects on growth, form, and wood properties of Pinus radiata cuttings up to age 12 years. N. Z. J. For. Sci. 2004, 34, 255-271.

105. Megraw, R.A. Wood Quality Factors in Loblolly Pine: The Influence of Tree Age, Position in Tree, and Cultural Practice on Wood Specific Gravity, Fiber Length and Fibril Angle; TAPPI Press: Atlanta, GA, USA, 1985; p. 88.

106. Kennedy, R.W. Coniferous wood quality in the future: Concerns and strategies. Wood Sci. Technol. 1995, 29, 321-339. [CrossRef]

107. Kimberley, M.O.; McKinley, R.B.; Cown, D.J.; Moore, J.R. Modelling the variation in wood density of New Zealand-grown Douglas-fir. N. Z. J. For. Sci. 2017, 47, 15. [CrossRef]

108. Haslett, A.N. Properties and Utilisation of Exotic Speciality Timbers Grown in New Zealand. Part III: Cypresses Chamaecyparis lawsoniana (A. Murr.) Parl. X Cupressocyparis leylandii (Jacks et Dall.) Dall. Cupressus lusitanica Mill. Cupressus macrocarpa Hartw.; New Zealand Forest Research Institute: Rotorua, New Zealand, 1986; Bulletin 119; p. 12.

109. Todoroki, C.L.; Low, C.B.; McKenzie, H.M.; Gea, L.D. Radial variation in selected wood properties of three cypress taxa. N. Z. J. For. Sci. 2015, 45, 24. [CrossRef]

110. Jones, T.G.; Low, C.B.; O'Callahan, D.R.; Chittenden, C.M. Variation in the wood properties of coast redwood trees in New Zealand. N. Z. J. For. Sci. 2014, 44, 11. [CrossRef]

111. Meason, D.; Riddell, M.; O'Callahan, D.; Thumm, A. Getting to the heart of coast redwood durability. N. Z. Tree Grow. 2018, in press.

112. Cookson, L.J.; McCarthy, K.J. Influence of tree age and density on the above-ground natural durability of eucalypt species at Innisfail. Aust. For. 2013, 76, 113-120. [CrossRef]

113. Moya, R.; Bond, B.; Quesada, H. A review of heartwood properties of Tectona grandis trees from fast-growth plantations. Wood Sci. Technol. 2014, 48, 411-433. [CrossRef]

(C) 2018 by the authors. Licensee MDPI, Basel, Switzerland. This article is an open access article distributed under the terms and conditions of the Creative Commons Attribution (CC BY) license (http://creativecommons.org/licenses/by/4.0/). 